\title{
Leaving Gaia behind: The ethics of space migration in Cixin Liu's and Neal Stephenson's science fiction
}

\section{JOHANNES D. KAMINSKI}

DOI: https://doi.org/10.31577/WLS.2021.13.2.1

Until recently, the imperialist gesture of the "land-grab" dominated the vast literary corpus of space exploration fiction. ${ }^{*}$ Here, conquered extraterrestrial territories provided new livelihoods, imitating the ambitions of European and American colonial masters of the 19th and 20th centuries. There is an obvious continuity between the conquest of exotic islands and interplanetary missions, between adaptation to foreign climates and life in air-locked habitats, and between encounters with indigenous populations and alien life forms. Such narratives reiterate the trope of the "quest" and culminate in the return to one's fatherland - either physically or, at least, through acquired information that is transmitted back to Earth. Recent examples of space exploration fiction, however, focus on terminal one-way journeys, in which the point of departure disappears. Once the surface of planet Earth becomes uninhabitable, space migration no longer represents colonial expansion, but turns into a matter of survival, forcing humankind to depart from its native habitat to avoid extinction. These scenarios appear in the Chinese author Cixin Liu's trilogy Remembrance of Earth's Past (地球往事, Diqiu wangshi), which includes The Three-Body Problem (三体, San Ti, 2008; Eng. trans. 2014), The Dark Forest (黑暗森林, Heian senlin, 2008; Eng. trans. 2015) and Death's End (死神永生, Sishen yongsheng, 2010; Eng. trans. 2016), as well as in Seveneves (2015), written by the American author Neal Stephenson. Exploring the possibility of moving human life into space stations, they put into question the earth-bound condition of biological life. Such radical habitat change, it turns out, is possible, though accompanied by a transformation of human ethics. Since the purpose of science fiction "is not to predict the future [...] but to describe reality, the present world" $(1979,165)$, as Ursula K. LeGuin posited, Stephenson's and Liu's texts can be taken for chilling explorations of the world of the Anthropocene. Can humanist values survive amid the challenge of living on a dying planet? Or will a new ethics arise from the ashes of consumer capitalism?

This article will first address the imaginary of space migration fiction from a cultural studies perspective. Since I draw upon both Chinese and American texts, I ask if the utilitarian view of nature is primarily a product of the Judeo-Christian tradition, and argue that the implied ethics are informed by modern pragmatic philoso-

* This paper is based on a guest lecture held at the Institute of World Literature, Slovak Academy of Sciences, on February 5, 2020. 
phy. Liu's and Stephenson's tableaus of humanity's future, where the survival of our species can only be afforded by drastic decisions, suggest the following questions: how does the future inscribe itself in behavioral codes? What anthropology is put forward? In what way are such scenarios a description of our present?

From a critical perspective, both authors are usually placed in the camp of techno-optimism. Since their popular works are shaped by and in turn inform contemporary ideas on the future of humanity, it is imperative to look behind the shiny chromium façades of space stations for their ideological contraband. Thus far, the political implications of Liu's fiction were regarded as secondary to his innovative storytelling (Li 2015, 537; Thieret 2015; Gilbey 2015, 159), yet his visions of humanity's dire future deserve more scholarly scrutiny. In public statements, both authors have asserted their frustration with present society's unwillingness to boldly pursue technological innovation. Dismissing our current skepticism towards modernism's faith in progress, Stephenson asserted: "The imperative to develop new technologies [is] the only way for the human race to escape from its current predicaments" (2014, xvii). In the same vein, Cixin Liu has insisted on the necessity of technological progress: "Probably, the solution is not to save Earth. It's too late. But if we hold back research, our fate will be sealed" (Yang 2018, 3; trans. J.K.). Although Liu's statement clearly has the natural sciences in mind, literary criticism may also contribute its fair share and accompany both authors' space enthusiasm with a running commentary.

\section{THE UTOPIA OF SPACE MIGRATION}

The heyday of US-American techno-optimism commenced after World War II, lasted until the Space Shuttle Challenger disaster in 1986 and was sealed by the end of the Cold War, when the space race narrative no longer appeared relevant. According to a genre timeline frequently invoked by science-fiction scholars, the second half of the 20th century saw masculinist techno-optimism replaced by a perspective that put the genre's conservative notions of civilization, society and gender into question (Broderick 2003; Roberts 2006; Vint 2021). Postwar science fiction is commonly identified with the "Big Three": Isaac Asimov, Arthur C. Clarke and Robert A. Heinlein. In such early examples, space acts not only as a realm that expands known territory, but represents a playground for the glory of humankind. With New Wave science fiction, a more critical type of novels started to show what awaits humanity in the vastness of space: human neuroses, the realization of humanity's limited intelligence and Le Guin's reminder that science fiction portrays the present instead of an anticipated future. While this historiographic timeline certainly lacks nuance and hardly does justice to the sophistication especially of Clarke's work, the two poles - techno-optimism and skepticism - can be seen as opposing ends on a scale, which help to identify tendencies rather than essential differences. Applied to this scale of measurement, Liu's and Stephenson's texts are hybrids. They inherit the technocratic optimism of postwar science fiction, but also draw the melancholic idea of humankind going extinct.

Today, the can-do optimism of the 1950s and 1960s may have faded, but has been reignited by the budding space rivalry between the United States of Ameri- 
ca and the People's Republic of China. The potential resurgence of the Cold War is not the only concern here. Confronted with drastic changes of the biosphere, space offers a convenient outlet for escapist fantasies. Startup millionaires and thought leaders tweet about cislunar colonies hosting up to 80,000 or even a trillion people (Musk 2012; Powell 2019). Stephen Hawking, the late British astrophysicist, speaking at a tech-summit in Beijing, argued that humanity must either leave Earth or go extinct (Rueckert 2017). While such visions can be downplayed as reiterations of postwar reveries, it is increasingly difficult to ignore the hidden message contained in such colorful statements. Ecological concerns are sacrificed for a supposedly higher goal; instead, exit strategies promise a land of golden opportunities and adventure. The renaissance of the Space Age imaginary comes at a time when we are facing rising global temperatures, acidification of waterways, accelerating habitat destruction and increased risk of extreme weather and food production shocks. Despite medical evidence of the medical risks of life in space (Longnecker, Manning, and Worth 2004, 17-27; Hill and Olson 2008), the idea of leaving our depleted environment appears politically more desirable than saving it. Such visionary plans derive their authority from a grand pretension. Claiming to concern themselves with long-term solutions for the benefit of humankind, they dismiss humanist ethics as a relic of the past.

Liu's and Stephenson's works dramatize this authoritative gesture through narrated time. Liu's trilogy, for example, puts forward a longue durée perspective on the existential threat of an alien attack in the future. The main narrative of the trilogy spans 500 years, when humanity prepares for the arrival of the Trisolarians, an alien civilization in need of a new habitable planet. In the American novel, narrated time stretches even further with a plot covering 5,000 years. As the Moon fractures into billions of asteroids, mankind has two years to migrate into the orbit before the lunar asteroids transform the planetary surface into an uninhabitable hellscape. Now castaways in space, the surviving population evolves and finally returns to the surface once temperatures have cooled. The book ends with a modified homo sapiens geo-engineering the atmosphere and returning to a radically geo-engineered environment back on Earth.

While both texts place no immediate attention on environmental concerns, their scenarios inevitably build on the macroscopic time horizon of the long-term effects of human interference with the biosphere. Individual biographies, the kernel of realist fiction, no longer suffice to tell the story; instead, multiple generations become part of a macro-narrative. Such transgenerational stories illustrate the catastrophic times that lie ahead of us. Humanity's existential predicament, however, is not a dead end; instead, both narratives marry the melancholic imagination of the apocalypse with a firm belief in technological salvation. Their complicated portraits of life beyond the planet synthesize a new anthropology of the Anthropocene.

\section{THE UTILITARIAN IMAGINARY}

Although the Anthropocene represents an era that comprehensively affects human life, its beginning is usually tied to the world system created by European empires, bourgeois capitalism and today's neo-liberalism. Multiple inception dates have 
been proposed: 1610, to emphasize the great impact of colonialism, global trade and coal on the biosphere (Lewis and Maslin 2015); 1784, to address the steam engine's role in large-scale industrialization (Crutzen and Stoermer 2000); and 1964, the year that counted the highest radiocarbon signal arising from nuclear tests, to highlight this technology's destructive power (Zalasiewicz, Waters, and Barnosky et al. 2015). Consequently, the inventions and cognitive frameworks of "Western" culture, conceived as a composite of European and North American philosophy, aesthetics and social practices, are regarded as the intellectual superstructure that helped create today's unhealthy relationship between human ambition and the finite resources of the planet.

Chinese scholars have met the Western-centric focus of Anthropocene definitions with both doubt and affirmation. Liu Dongsheng, a Chinese geologist, has challenged its modern genesis and claimed that mankind has been shaping the biosphere since the transition from hunter-gatherer to sedentism. Liu's "deep Anthropocene" reaches back 10,000 years and emphasizes the destructive tendency shared by all civilizations $(2004,369)$. In contrast, other Chinese scholars have affirmed the Western origin of the lifestyles that have led to the present predicament, emphasizing the moral superiority of traditional Chinese philosophy. The argument is that the principle of the harmony between nature and humans is embedded in foundational texts of Chinese antiquity, such as The Book of the Way (道德經, Dao De Jing, 6th c. BCE) (Wang 2018). Furthermore, Chinese holism is said to be immune against the binary world view of humans standing against nonhuman nature (Tang 2015; Tu 2001; Wei 2018). Such comprehensive statements overlap considerably with Western ecocentric thought, which has entered the mainstream of academic discourse in the humanities. This singular focus on the Anthropocene's Western origins, however, turns a blind eye on the utilitarian view of nature, as evinced by ancient Chinese texts other than The Book of the Way. From a historiographical perspective, "actual practices of the Chinese have hardly lived up to the ideal expressed in their traditions" (Snyder $2006,100)$. As a result, Chinese history indeed features large-scale deforestation and other environmental catastrophes which also led to the extinction of the Chinese elephant around $1000 \mathrm{CE}$ (128). In the 20th century, this utilitarian approach seamlessly integrated with socialist thought which further emphasizes the primacy of mind over matter. Mao Zedong's utopian idealism relentlessly pressed ahead with the conquest of nature and saw the transformation of the Mongolian grasslands into agricultural land (Shapiro 2001).

While the "shallow Anthropocene" approach allows for the thought-game that one must only abolish modern civilization for a return to a harmonious state, the "deep Anthropocene" concept stresses irreversibility. According to this logic, the utilitarian view of nature is ingrained in human civilizations, not just in the West, but also in early civilizations. In this light, accounts of indigenous populations living in harmony with nature, as observed in the Brazilian rainforest (Danowski and Viveiros de Castro 2016), are exceptions - or only made possible in low-density habitats. Once large populations occupy a stretch of land, the result are dramatic stand-offs between nature and men, a trope that features prominently in many mythological and histo- 
riographical accounts of early cultures. Such representations of catastrophic events have shaped notions of human-nature relationship and continue to serve as model scenarios. Arguably, the science-fiction texts discussed in the present article form part of a series that start with accounts of the Great Deluge, a seemingly universal event in the past (Frazer 1916). With the survival of mankind threatened by a natural disaster, narratives connect effects to causes, thus indicate the place of human agency in the creation. In this respect, the Chinese account puts forward a point of view that appears more congenial to our Promethean Age than the corresponding Biblical passage.

In the Old Testament, the great flood marks a watershed on the cosmic level (Blecher 2017, 129). The scripture places great importance on the natural disaster's correct interpretation as a punishment sent by an angry God. After taking notice of mankind's irreformable wickedness, God resolves to wipe his creation off the face of the earth. Only Noah's family is issued a warning and provided with the ark's building plan (Genesis 6:5-17). In Bible exegesis, the vessel was never understood as an engineering feat, but as an allegory of God's relationship with man. ${ }^{2}$ A similar interpretation of the deluge as divinely imposed punishment is put forward in the Quran (Neuwirth 2019, 385-386). In the end, God's magnanimity, condensed in the symbol of the rainbow, affords humanity a new start.

In Chinese historiography, Mencius' canonical account of the Great Flood, written in the 3 rd century $\mathrm{BCE},{ }^{3}$ contrasts significantly with the Biblical narrative. In opposition to rivalling Confucian thinkers, who shared some of Christianity's bleak anthropology, his basic assumption is that human nature is good and can be continually improved by self-cultivation. Mencius also applies this self-determined attitude to man's role in the universe. In his account of the deluge, nature is supposed to be manipulated by man: "In the time of [Shun], the water, flowing out of their channels, inundated the Middle Kingdom. Snakes and dragons occupied it, and the people had no place where they could settle themselves. In the low grounds they made nests for themselves, and in the high grounds they made caves" (Mencius 1891, 92). As people are displaced from their homes, the flood event appears to modern readers as a challenge in logistics and engineering rather than divine punishment. The account continues:

Shun employed Yu to reduce the waters to order. Yu dug open their obstructed channels, and conducted them to the sea. He drove away the snakes and dragons, and forced them into the grassy marshes. On this, the waters pursued their course through the country, even the waters of the [Jiang], the [Huai], the Han, and the Yellow [Rivers], and the dangers and obstructions which they had occasioned were removed. The birds and beasts which had injured the people also disappeared, and after this men found the plains available for them, and occupied them (93).

Yu's engineering skills tackle the deadly flood so human life can flourish again. In catastrophic times, Mencius does not require the population to be God-fearing; instead, rulers must demonstrate their ability to create order. Humans must not co-exist alongside snakes and dragons, but shall live in terraformed landscapes. Mencius' account is strikingly secular and technocratic. The ruler's task is to transform nature into culture. Indeed, this passage indicates that the complicated dichot- 
omy nature/culture is not unique to the Judeo-Christian tradition, but is also rooted in the Chinese one. While only the former positions the divine outside creation, the latter's cosmos still allows for the utilitarian, even hedonistic imposition of human needs on the non-human environment (Arie 2017, 90). Since the environment lacks prestabilized harmony, it is man's call to embrace his position as a transformer of the natural world.

Indeed, this proactive stance towards nature is not limited to Mencius, but extends into the ecological impact state actors had on natural environments through to the large-scale natural destruction observed in China in the 20th and 21st centuries. Although King Yu would not have been impressed with the side effects, he would have applauded the ambition to create a human-centered biosphere. Mencius's account does not merely serve as template for the Chinese context, but forms a fitting blueprint for humankind's departure from its native planet. In comparison, Genesis illustrates a rather archaic perspective on human agency. Even if mankind was meant, in the Biblical formulation, to "have dominion over the fish of the sea, and over the fowl of the air, and over every living thing that moveth upon the earth" (Genesis 1:28), extending this already drastic control to include inanimate matter represents an infringement upon God's prerogatives.

\section{ABANDONING THE PLANET}

Literary science fiction excels at dealing with humanity in crisis. Once the planet's surface becomes uninhabitable, there are two options. First, to go underground, a trope that features prominently in subterranean fiction (Fitting 2004), and second, space migration. During the Second Industrial Revolution, fiction became growingly interested in incorporating scientific ideas into such narratives, as evidenced by Jules Verne's From the Earth to the Moon (De la Terre à la Lune, 1865) and Edward Everett Hale's The Brick Moon (1869). After a slight delay, Chinese authors started to pen their own visions of space travel. In Huangjiang Diaosou's Tale of Moon Colonists (月球之民地小說, Yueqiu zhimindi xiaoshuo, 1904-1905), human explorers encounter, to their great shock, a superior civilization on the Moon.

Despite the boom of techno-optimistic science fiction in America, the beginning of the Cold War also inaugurated, owing to the nuclear threat, a postapocalyptic imaginary of planetary destruction (Hammond 2006; Williams 2011). For example, Ray Bradbury's short-story collection The Martian Chronicles (1950) follows the fate of humans stranded on Mars after a nuclear war devastated Earth, who are cut off from home and start adapting to life on the Red Planet. In the same year, Robert A. Heinlein published Farmer in the Sky (1950). Here, Earth, overcrowded and plagued by famine, is happily abandoned by space colonists who are heading to Ganymede, one of Jupiter's moons. In contrast, optimism prevailed in Chinese science fiction of the time. As the world of letters became increasingly dominated by politics, there existed little tolerance for pessimistic scenarios. Wenguang Zheng's short story of 1957, “Builders of Mars" (火星建設者, “Huoxing jianshezhe"), tells of the interstellar success story of socialism as Martian colonization begins. However, Cixin Liu's prose brought an unprecedented pessimism to science fiction. In contrast 
to the sanguine Star Trek universe, where different alien civilizations engage in largely peaceful political collaboration, Liu's trilogy portrays the universe as a Darwinian battleground. Humanity does not act as a bringer of civilization, but faces destruction by mightier beings. In contrast to classics such as H.G. Wells's War of the Worlds (1898), mankind is not saved by earthly pathogens that turn out deadly for the invaders; instead, the attack reveals our fundamental incapability to perform large-scale rescue operations.

In Liu's trilogy, the basic assumption is that every highly developed intelligence would rather destroy lesser ones than allowing them to develop into future rivals. Luo $\mathrm{Ji}$, one of the protagonists, explains this principle as follows:

The universe is a dark forest. Every civilization is an armed hunter stalking through the trees like a ghost, gently pushing aside branches that block the path and trying to tread without sound. Even breathing is done with care. The hunter has to be careful, because everywhere in the forest are stealthy hunters like him. If he finds other life [...] there's only one thing he can do: open fire and eliminate them. [...] This is the picture of cosmic civilization $(2015,484)$.

Extermination is also what the Trisolarians have in mind for Earth. They intend to wipe out the human population to create space for their own people. Thrilled by this prospect, a small segment of the population, the Earth Trisolaris Organization, even embraces the advent of the Trisolarians. Led by Mike Evans, an American environmentalist, their argument is that Earth's annexation by a more intelligent species is preferable to keeping humans in power. Meanwhile, the rest of humanity, led by the United Nations, starts working on saving mankind from extinction. Given the four-hundred years needed for the Trisolarians' journey from Alpha Centauri to the Solar System, there is plenty of time to explore different solutions. In face of the alien civilization's technological superiority, state leaders initially agree to strive for the stars: "a [...] realistic goal would be to construct starships to enable a small portion of the human race to flee to outer space, thereby avoiding the total extinction of human civilization" (39). The plan is that all developed nations will funnel their resources into building the necessary technology, including a space elevator and nuclear fusion propulsion. Yet the "Human Escape Plan" is quickly abandoned - for reasons that will be discussed in the next section.

Other plans include the construction of a defensive space fleet, a rather hopeless endeavor, and the appointment of four "Wallfacers", that is, strategists with access to unlimited budgets, who are not accountable to anyone. Luo Ji, an inconspicuous academic, becomes one of them and discovers the "dark forest" principle: if one hunter is about to attack another one, it becomes strategically desirable to involve a third hunter. The idea is that humans can broadcast the coordinates of Earth into the universe, thereby exposing themselves to a preventive strike by a third civilization. This would wipe out not only humanity but also the prospective colony of the Trisolarians, who try to block the broadcast into space. Luo Ji succeeds in bypassing their shield, which leads to a short-term triumph: the Trisolarians turn away from Earth. However, the imminent destruction is only postponed, and humanity retreats into large-scale space cities behind Jupiter - only to be wiped out regardless. This melan- 
cholic end is somewhat balanced by a narrative trick that allows the book to cover the remaining time until the Big Crush, the end of the universe itself, set eighteen million years in the future. Two remaining humans can escape into a "pocket universe", from where they can inhabit a space outside time.

In Stephenson's Seveneves, the UN is tasked with an analogous endeavor, yet must act much faster. After an unknown projectile pierces the Moon, space migration must be accomplished within two years only; by then, the broken satellite will break into ever smaller fragments with exponential increase. Dissolved into myriad meteors, the satellite's fragments will eventually engulf the planet in a sea of fire. As the remaining people on Earth await the deadly impacts, 1,500 people are already stationed in the orbit. Subsequently, the total population of the space station shrinks to sixteen people, and, after another incident, to seven women. In order to ensure the survival of humanity, the entire concept of progeny is overhauled. Using parthenogenesis, a form of reproduction known from insects, worms and reptiles, the seven women recombine their own DNA-strains and start producing non-identical clones of themselves. At this point, the novel makes a bold leap. In the year $7000 \mathrm{CE}$, the offspring of the eponymous seven Eves have installed themselves on a ringworld, an interconnected belt that revolves around Earth. By now, all fragments of the Moon have crashed into the surface and left the environment ready for large-scape terraforming operations. A hospitable environment is created through advanced forms of geo-engineering. Our species, after having undergone radical change itself, descends from space to step on old, yet unfamiliar ground.

The notion of a thoroughly transformed, man-made biosphere forms part of a series that begins with King Yu rather than Noah. While the latter could rely on God's grace, Shun had to take the right decisions, including the recruitment of Yu, the engineer. But while the ancient Chinese text praises the creation of artificial environments to host human life, Mencius' report does not mention the changes within the populations itself. In the Space Age, however, such manipulations are exacerbated by biopolitical fantasies.

\section{“OBLIQUE” ETHICS}

The fundamental idea of space migration is the creation of a global state of emergency which provides new legitimacy for biopolitical measures. According to Giorgio Agamben, this kind of situation allows for a convenient suspension of the rule of law, granting political leaders the power to decide who should live and who should be left to die $(2002,130)$. While a tyrant is rarely asked to justify the rationale of such decisions, Liu's and Stephenson's texts put forward scenarios in which decisions are presented as careful trade-offs between losses and gains. The idea of ensuring the survival of selected individuals at the expense of others stands at the heart of pragmatic ethics, a line of inquiry that has a penchant for dramatic thought-games.

In Stephenson's Seveneves, a managerial elite approaches decision-making in a rather postdemocratic fashion. There is no plebiscite on how to proceed; instead, the masses are nudged into accepting the inevitable. In a worldwide broadcast, a geneticist explains the procedure: 
We ask every village, town, city, and district to perform a Casting of the Lots and to choose two young persons, a boy and a girl, as candidates for training and inclusion in the crew of the Cloud Ark. [...] Our objective is to preserve, as best we can, the genetic and the cultural diversity of the human race. [...] The boys and the girls so chosen [...] will be gathered together in a network of camps and campuses, where they will be trained for the mission they are to undertake $(2015,58)$.

The wording, as an informed listener in the book knows, is highly euphemistic: "It would get competitive. Perhaps brutally so" (58-59). In the meantime, the world population resigns itself into accepting its doom. Those who feel depressed about the situation can take euthanasia pills that are handed out by the governments - free of charge (290). Overall, the rescue project enjoys wide support: "Oh, there had been some outbreaks of civil disorder, but for the most part people were taking it surprisingly calmly" (196). In Stephenson's novel, a new ethics will not be forged on Earth, where a sense of collective sacrifice prevails, but in space.

In Liu's first instalment of the trilogy, state leaders face a dilemma. Although the "Human Escape Plan", involving the construction of large-scale generation ships, is most promising for the preservation of mankind's existence, the plan is unworkable. The preferential treatment of a future elite - taking advantage of a century, possibly centuries, of economic sacrifice - would risk major social unrest, perhaps a world war. A supporter of the Trisolarian invasion ponders: "Who goes and who remains involves basic human values, values which in the past promoted progress in human society, but which, in the face of ultimate disaster, are a trap. Right now, the majority of humanity has not realized how deep this trap is. [...] No human can escape this trap" $(2015,44)$. With some delay, state leaders also become cognizant of mankind's impasse situation and declare this plan illegal. Four-hundred years later, after humanity's retreat into Jupiter's shadow, there is renewed interest in the Escape Plan, this time in connection with lightspeed travel. But once again, this route is seen as incompatible with human rights, and its charismatic proponent is put to death (2016, 460). As the trilogy ends with the comprehensive destruction of the Solar System, it turns out that space migration was the only realistic hope that humanity ever had. Only two renegade spaceships escape into the darkness of space and eventually find new habitats.

While Stephenson demonstrates successful space migration and Liu its fateful cancellation due to humanist concerns, both authors are united in their positive assessments of an escape plan, including the preferential treatment of selected individuals. Human rights, they argue, are incompatible with the dawn of the Space Age. In view of the Universal Declaration of Human Rights, adopted by the General Assembly of the UN in 1948, this plan includes a direct violation of the right of self-determination (Article 1) and the inherent right to life (Article 6). Arguably, the Universal Declaration is an inadequate frame of reference; after all, it was not intended for the cataclysmic scenarios envisioned by both authors, but to promote peace among nation states after two world wars. To fill this gap, both authors put forward an alternative approach, one that seamlessly connects to the worst-case scenarios imagined in pragmatic ethics. Both authors' advocacy for a space elite can be seen as a dra- 
matic exploration of the doctrine of the double effect, as brought to prominence by Philippa Foot's discussion of collateral damage. Accordingly, "it is sometimes permissible to bring about by oblique intention what one may not directly intend" $(2002,24)$. Foot's point of reference is the "trolley problem". The driver of a runaway trolley has two options: either to follow the straight track and steer the vehicle into a group of five - or to divert the trolley to the sidetrack, killing one person only. Since the driver faces a conflict of negative duties, Foot prefers him to choose the smaller damage. Arguably, Stephenson and Liu also stage scenarios of oblique intention, as the formation of a space elite is a question of letting the remaining population die, a scenario deemed preferable to universal death. In short, in a situation where everyone is bound for death, the principal question is not who survives, but whether someone survives at all.

In the past, such survivalist ethics were already applied to pressing global issues. In view of overpopulation and migration, the American ecologist Garrett Hardin recommended to withhold food aid from populations that experience emergency situations; after all, such support undermines local efforts of population control (1974, 564). Today, Hardin's proposals are classified as the ideological products of ethno-nationalism with genocidal undercurrents. As if intended to showcase the positive choice for human life that is judged as superior to others, Liu's third tome illustrates the awkward choices involved in such rescue operations. With three remaining seats available in their spacecraft, one crew member despairs, wondering to herself: "There are billions of people on the Earth. [...] How am I supposed to pick?" Facing a group of children, she is unable to act. Her hard-boiled colleague, however, steps in and improvises an oral exam: "Everyone, listen up. I'm going to ask three questions. Whoever gives the right answers first gets to come with us" $(2016,391)$. In a way, this procedure recalls gaokao, the life-determining university exam procedures in China. But instead of determining a person's chance of becoming a blue- or white-collar worker, it means the difference between life and death.

Applying Foot's and Hardin's pragmatism to Liu's scenario shows that the good intention of sticking to basic human values becomes irrelevant in emergency situations. Alongside Friedrich Nietzsche's On the Genealogy of Morals (Zur Genealogie der Moral, 1887), they argue that ethical codes do not represent timeless values, but result from concrete historical circumstances. In times of crisis, sticking with the moral constraints of another age is not only impractical, but misses the entire point of behavioral codes. The present examples of Space Age fiction would agree. The pragmatic effect of humanist virtue is nil: neither would the Trisolarian threat go away if humanity demonstrated noble behavior, nor would the Moon realign into a spherical satellite if nobody entered the orbit. The staggering passivity of Stephenson's world population is possibly rooted in this realization: no matter which route the trolley takes, one will be hit either way.

\section{SPACE ETHICS}

In contrast to Victorian literature, e.g. Joseph Conrad's Heart of Darkness (1899), space migration fiction entertains a relaxed attitude towards the realignment of be- 
havioral standards. In Liu's trilogy, such transformations are observed on board the spaceships Gravity and Blue Origin; in Stephenson's novel, hell breaks out after the orbiting survivors witness the destruction of the planetary surface.

After 200 years have passed since the Trisolarians communicated their plans, the first interstellar battleships are ready. As they are attacked by an invincible remote-controlled alien object, several commanders seize the moment and leap into the unknown. They become mutinous, defy orders to return to Earth and break off contact. From this moment on, they face a new enemy, each other. Since resources are limited, the most promising way of long-term survival implies the siege of other escaped ships. During the standoff between two vessels, one captain tries to justify his decision: "The birth of a new civilization is the formation of a new morality.' He removed the first safety lock of the H-bomb warheads. 'When they look back in the future on everything we've done, it may seem entirely normal"' $(2015,456)$. Unfortunately, the other ship's captain pre-empts his decision and pulls the trigger earlier.

Escaping into space, we learn, is not just a physical process, where one moves along new coordinates, but it also implies a moral transformation. Human morality as we know it developed on a lush planet that could, in theory, feed six billion people. In space, however, this morality breaks down. Groups of survivors can only exist at the expense of others, whose energy sources must be exploited and whose protein is needed for sustenance. The mutineers take to eating defenseless colleagues who lie in a state of hibernation. Eventually, one of the cannibal-carrying space ships is caught. Back on Earth, their captain is put on trial and defends himself with an anthropological argument:

Life reached an evolutionary milestone when it climbed onto land from the ocean, but those first fish that climbed onto land ceased to be fish. Similarly, when humans truly enter space and are freed from the Earth, they cease to be human. [...] When you think about heading into outer space without looking back, please reconsider. The cost you must pay is far greater than you could imagine $(2016,116)$.

The trope of cannibalism epitomizes the new morality that awaits us in space. Hanging on to old regimes of morality, like not harming others and not using other humans as food sources, becomes an obstacle for survival.

It is difficult to tell apart the new morality, as asserted by the captain, from the "natural state of men", which Thomas Hobbes defined as "mere war, and that not simply, but a war of all men against all men" $(1949,29)$. Does the ultimate goal of mankind, the conquest of space, entail its return to a state that civilization that is "deprived of all that pleasure and beauty of life, which peace and society are wont to bring with them" (30)? In Liu's text, this devolutional perspective on space travel is entertained by a group of people who prefer to abandon technological advancement altogether. Their argument is that "once humanity headed for space, it would inevitably regress socially. Space was like a distorting mirror that magnified the dark side of humanity to the maximum" $(2016,409)$. The Space Age sees the advent of irritating patterns of behavior that can be interpreted as a return to plain barbarism or, without moral judgement, as ethical renewal. Both narratives stress the inevitability of this transformation lest humanity should go extinct. Here, the trolley problem is modified though 
factoring in the driver's existential needs. The question is not how many deaths he will take into account, one or five, but what he intends to do with the corpses. Will he take advantage of this free meal or will he remain hungry?

Cannibalism is also a pertinent trope in Stephenson's Seveneves. Once in orbit, the space population gets embroiled in the first interstellar civil war. After divisions between two factions deepen, one group intends to leave for Mars, a plan at odds with scientific advice. As expected, the pioneers quickly discover that their food sources dwindle, so they turn to protein sourced from other humans. As the two warring parties resume contact, the commander of the space station wonders:

"What have you been eating?"

Aida snapped her head around, as if surprised by the question, and looked quizzically into the camera. "Each other. Dead people, I mean."

There was a long silence during which [they] all exchanged looks. The terrible thing was that they had considered doing the same thing, many times. Every freeze-dried corpse that they jettisoned was a big collection of protein and nutrients that, from a certain point of view, could seem mouthwatering.

Seeming to read their minds, Aida went on: "And you?"

"You mean, have we resorted to eating dead people? No," Doop said (520).

After further battle, the final survivors move the space station into an asteroid's cavity. Here, they set up a colony from which, 5,000 years later, the planet will be repopulated, and from this moment onwards, there are no further instances of cannibalism.

As the ultimate emblem of an inverted world order, the perception of cannibalism used to divide the human population into those who observe restraint and those who regress into savagery. In Daniel Defoe's Robinson Crusoe (1719), the first thing that the protagonist teaches Friday is the godlessness of this practice. In pragmatic ethics, this distinction is levelled out. Foot is surprisingly forgiving with regard to emergency cannibalism, giving the case of a shipwreck whose only survivors are two sailors and one cabin boy, in which eventually, the former two kill and eat the latter. According to Foot, this case is similar to the trolley problem:

Here again there is no conflict of interests so far as the decision to act is concerned; only in deciding whom to save. Once again it would be reasonable to act, though one would respect someone who held back from the appalling action either because he preferred to perish rather than do such a thing or because he held on past the limits of reasonable hope (2002, 31-32).

In Foot's analysis, non-cannibalism is merely respectable rather than an indication of ethical standards. New circumstances legitimize radical behavioral change. The faint pangs of survivor's guilt may arise occasionally, but are dismissed as reminders of an obsolete value system.

\section{CONCLUSION}

The technocratic imaginary, as expressed in Liu's and Stephenson's novels, transcends cultural binaries. Liu is not particularly influenced by Chinese antiquity, nor Stephenson by the Christian heritage. Instead, both build on a utilitarian imaginary that commences with Mencius' account of King Yu's waterworks and only 
reaches its most extreme form under the global capitalism forged by Western powers. In the 20th century, Mao's conquest of nature builds on Western materialism and Chinese utilitarian thought in equal parts. In comparison, the Judeo-Christian myth of the Great Deluge appears largely irrelevant today, for it fails to emphasize the transformative power of human agency on the planet. For Noah's family, the flood represents a test in faith rather than a challenge for their engineering skills.

Liu's and Stephenson's striking tableaux of humanity's future build on this utilitarian approach. The sudden transformation of the Earth's satellite into a bringer of doom and the long-term annunciation of humanity's extinction at the hands of a superior civilization are eerie scenarios that address fundamental anxieties of the present, notably the potentially drastic impact of climate change on human livelihoods from a longue durée perspective. As opposed to humanity's indecisive reactions to climate change, these gigantic threat scenarios are different, for they trigger global states of emergency where the rule of law is replaced by biopolitical choices. In the Space Age, we learn, humanist values no longer apply, and there exists no position of righteousness, like Noah's. Once it is too late to save Earth, humanity faces an overhaul of its value system, possibly also a renewed Hobbesian "war of all men against all men". Basic human needs, such as nutrition, are not solved by ultra-hygienic technology, like the "Replicator" in the Star Trek universe, but lead to cannibalism. Together with parthenogenesis, the comprehensive transplantation of life into space and planetary geoengineering, such speculative ideas have one message: when faced with adversity, humans can survive anything - but at a sufficiently high cost. As social norms collapse and the struggle of survival begins, humanity cancels its subscription to the previous foundation of transcultural universalism, the anthropology put forward by the Universal Declaration. Skeptics may argue that this altered version of ourselves is hardly worth preserving. In a world where eating human protein is "reasonable" and its rejection merely "respectable", humanity's transformation into a space caste does not honor the glorious future invoked in postwar science fiction, but heralds the rise of the Morlocks, the cannibalistic offspring of mankind, as imagined in Wells's The Time Machine (1895).

Applying the ethical primitivism of these novels to present concerns about the future reveals a paradox. Although it remains technically impossible to conceive of humanity's migration into space, we already brace ourselves for the drastic transformation of our value systems. As global temperatures rise, extreme weather events become more frequent and food production shocks probable, we may witness this transformation - not after our ascension into space, but here on Earth already. In this light, Liu's and Stephenson's sinister space stations could be read as metaphors for the biopolitics of the near future where Philippa Foot's neat scenarios give way to Garrett Hardin's quasi-genocidal thought-games. In Liu's and Stephenson's global states of emergency, the only way forward is to overcome squeamish commitment to individual rights. To ecocentric thinkers, the erratic agency of Gaia serves as a call to transform the present world order into a more sustainable form of cohabiting with non-human agents. To trolley drivers, however, it may appear like a welcome opportunity to cleanse the tracks of superfluous pedestrians. 
1 The interview was published in German. The original passage reads: "Die Lösung wird womöglich nicht darin bestehen, die Erde zu retten. Wenn wir aber die Forschung aufhalten, ist unser Schicksal besiegelt."

2 According to Augustine, one of the Church fathers, the ark is an allegory of Jesus Christ. The ark's door, for example, represents the wound in Christ's side $(2002,683)$.

3 Mencius' flood account is just one among many. The fullest early recounting of the story appears in the Book of Documents (書經, Shujing), one of the Five Confucian classics. In contrast to Mencius, however, this flood narrative is somewhat sketchy (Lewis 2006, 29-30).

\section{LITERATURE}

Agamben, Giorgio. 2002. Homo sacer: Die souveräne Macht und das nackte Leben. Trans. by Hubert Thüring. Frankfurt am Main: Suhrkamp.

Arie, Daisuke. 2017. “Confucianism.” In The Bloomsbury Encyclopedia of Utilitarianism, ed. by James E. Crimmins, 90-91. London: Bloomsbury Academic.

Augustine. 2002. The City of God Against the Pagans. Ed. by Robert W. Dyson. Cambridge: Cambridge University Press.

Blecher, Adi. 2017. "Noah's Curse: Punishment and Paradox." Journal for Ancient Near Eastern and Biblical Law 23: 123-135.

Broderick, Damien. 2003. "New Wave and Backwash: 1960-1980.” In The Cambridge Companion to Science Fiction, ed. by Edward James and Farah Mendleson, 48-64. Cambridge: Cambridge University Press. DOI: https://doi.org/10.1017/CCOL0521816262.004.

Crutzen, Paul J., and Eugene F. Stoermer. 2000. "The 'Anthropocene'." Global Change Newsletter (IGBP) 41: 17-18.

Danowski, Déborah, and Eduardo Viveiros de Castro. 2016. The Ends of the World. Trans. by Rodrigo Guimaraes Nunes. Cambridge: Polity.

Fitting, Peter. 2004. Subterranean Worlds: A Critical Anthology. Middletown, CT: Wesleyan University Press.

Foot, Philippa. 2002. "The Problem of Abortion and the Doctrine of the Double Effect." In Virtues and Vices and Other Essays in Moral Philosophy, Philippa Foot, 20-32. Oxford: Oxford University Press. DOI: https://doi.org/10.1093/0199252866.003.0002.

Frazer, James George. 1916. “Ancient Stories of a Great Flood.” The Journal of the Royal Anthropological Institute of Great Britain and Ireland 46, July-December: 231-283. DOI: https://doi. org/10.2307/2843393.

Gilbey, John. 2015. "After the Cataclysm.” Nature 521 (7551): 159. DOI: https://doi.org/10.1038/521159a. Hammond, Andrew, ed. 2006. Cold War Literature: Writing the Global Conflict. London: Routledge.

Hardin, Garrett. 1974. "Living on a Lifeboat." BioScience 24, 10: 561-568.

Hill, Joseph A., and Eric N. Olson. 2008. "Cardiac Plasticity." The New England Journal of Medicine 358, 13: 1370-1380. DOI: https://doi.org/10.1056/NEJMra072139.

Hobbes, Thomas. 1949. De Cive: Or the Citizen. Ed. by Stirling P. Lamprecht. New York, NY: Appleton-Century-Crofts.

IPCC (Intergovernmental Panel on Climate Change). 2018. "Global Warming of $1.5^{\circ} \mathrm{C}$ : An IPCC Special Report.” Accessed July 1, 2020. https://report.ipcc.ch/sr15/pdf/sr15_spm_final.pdf.

Israel, Jonathan. 2011. Democratic Enlightenment: Philosophy, Revolution, and Human Rights, 1750-1790. Oxford: Oxford University Press.

Keel, Hee-Sung. 2007. Meister Eckhart: An Asian Perspective. Leuven: Peeters Publishers.

Latour, Bruno. 2018. Down to Earth: Politics in the New Climatic Regime. Trans. by Catherine Porter. Cambridge: Polity.

LeGuin, Ursula K. 1979. "Introduction to The Left Hand of Darkness." In The Language of the Night: Essays on Fantasy and Science Fiction, 2nd edition, 155-159. New York, NY: G.P. Putnam's Sons. 
Lewis, Mark Edward. 2006. Flood Myths of Early China. Albany, NY: State University of New York Press. Lewis, Simon L., and Mark A. Maslin. 2015. “Defining the Anthropocene." Nature 519 (7542): 171-180. DOI: https://doi.org/10.1038/nature14258.

Li, Hua. 2015. “The Political Imagination in Liu Cixin's Critical Utopia: 'China 2185'.” Science Fiction Studies 42, 3: 519-540. DOI: https://doi.org/10.5621/sciefictstud.42.3.0519.

Liu, Cixin. 2015. The Dark Forest. Trans. by Joel Martinsen. London: Head of Zeus.

Liu, Cixin. 2016. Death's End. Trans. by Ken Liu. London: Head of Zeus.

Liu, Dongsheng. 2004. "Kaizhan 'Renleishi' Huanjing Yanjiu” [Beginning of Anthropocene Research]. Quaternary Science 24, 4: 369-378. DOI: https://doi.org/10.3321/j.issn:1001-7410.2004.04.001.

Longnecker, David E., Frederick J. Manning, and Melvin H. Worth. 2004. Review of NASA's Longitudinal Study of Astronaut Health. Washington, DC: The National Academies Press.

Mencius. 1891. Works. Trans. by James Legge. New York, NY: John B. Alden.

Musk, Elon. 2012. Twitter Post. November 27. Accessed July 1, 2020. https://twitter.com/elonmusk/ status/273483420468932608.

Neuwirth, Angelika. 2019. The Quran and Late Antiquity: A Shared Heritage. Oxford: Oxford University Press. DOI: https://doi.org/10.1093/oso/9780199928958.001.0001.

Powell, Corey S. 2019. “Jeff Bezos Foresees a Trillion People Living in Millions of Space Colonies. Here's What He's Doing to Get the Ball Rolling." NBC May 15. Accessed July 1, 2020. https://www.nbcnews.com/mach/science/jeff-bezos-foresees-trillion-people-living-millions-space-colonies-here-ncna1006036.

Roberts, Adam. 2006. The History of Science Fiction. London: Palgrave Macmillan. DOI: https://doi. org/10.1057/9780230554658.

Rueckert, Phineas. 2017. "Earth Will Become 'Sizzling Ball of Fire' in 600 Years: Stephen Hawking." Global Citizen. Accessed July 1, 2020. https://www.globalcitizen.org/en/content/stephen-hawkingearth-sizzling-ball-of-fire/.

Shapiro, Judith. 2001. Mao's War Against Nature: Politics and the Environment in Revolutionary China. Cambridge: Cambridge University Press. DOI: https://doi.org/10.1017/CBO9780511512063.

Snyder, Samuel. 2006. "Chinese Traditions and Ecology: Survey Article." Worldviews: Global Religions, Culture, and Ecology 10, 1: 100-134. DOI: https://doi.org/10.1163/156853506776114465.

Stengers, Isabelle. 2015. In Catastrophic Times: Resisting the Coming Barbarism. Trans. by Andrew Goffey. London: Open Humanities Press.

Stephenson, Neal. 2014. "Preface: Innovation Starvation." In Hieroglyph: Stories and Visions for a Better Future, ed. by Ed Finn and Kathryn Cramer, xiii-xx. New York, NY: William Morrow.

Stephenson, Neal. 2015. Seveneves. London: Borough Press.

Tang, Yijie. 2015. Confucianism, Buddhism, Daoism, Christianity and Chinese Culture. Berlin, Springer. DOI: https://doi.org/10.1007/978-3-662-45533-3.

Thieret, Adrian. 2015. "Society and Utopia in Liu Cixin." China Perspectives 1: 33-39. DOI: https://doi. org/10.4000/chinaperspectives.6643.

Tu, Weiming. 2001. "The Ecological Turn in New Confucian Humanism: Implications for China and the World." Daedalus 130, 4: 243-264.

Vint, Sherryl. 2021. Science Fiction. Cambridge, MA: The MIT Press.

Wang, Jinghui. 2018. "Re-interpreting 'Dao De Jing' from an Ecological Perspective." Comparative Literature Studies 55, 4: 812-823. DOI: https://doi.org/10.5325/complitstudies.55.4.0812.

Wei, Qingqi. 2018. “Toward a Holistic Ecofeminism: A Chinese Perspective." Comparative Literature Studies 55, 4: 773-786. DOI: https://doi.org/10.5325/complitstudies.55.4.0773.

Williams, Paul. 2011. Race, Ethnicity and Nuclear War: Representations of Nuclear Weapons and Post-Apocalyptic Worlds. Liverpool: Liverpool University Press. DOI: https://doi.org/10.2307/j.ctt5vjdcf.

Yang, Xifan. 2018. "Ein Literaturheft Cixin Liu: Wir müssen schnellstmöglich technologische Wunder vollbringen.” Zeit-Magazin 42, October 10. Accessed July 1, 2020. https://www.zeit.de/zeit-magazin/2018/42/science-fiction-autor-liu-cixin-china/seite-3.

Zalasiewicz, Jan, Colin N. Waters, Anthony D. Barnosky et al. 2015. "Colonization of the Americas, 'Little Ice Age' Climate, and Bomb-Produced Carbon: Their Role in Defining the Anthropocene." The Anthropocene Review 2, 2: 117-127. DOI: https://doi.org/10.1177/2053019615587056. 
Science fiction. Ethics. Anthropocene. Cannibalism. Cixin Liu. Neal Stephenson.

In Cixin Liu's trilogy Remembrance of Earth's Past (2008-2010) and Neal Stephenson's Seveneves (2015), the surface of planet Earth becomes uninhabitable amid global states of emergency, and central governments devise radical plans to ensure the survival of the human species. In contrast to the Old Testament, where human emancipation from nature is punished, Chinese antiquity's narratives of large-scale engineering projects are surprisingly compatible with the modern mindset which regards nature in utilitarian terms. Contemporary science fiction does not simply inherit this techno-optimistic stance, but fleshes out possible futures that are shaped by biopolitical decisions. In Stephenson's and Liu's prose, the proposed escape plans only benefit small segments of the population. While such procedure is incompatible with human rights, which emphasize the value of the individual over the collective, contemporary pragmatic ethics interprets such behavior as rational. Applied to more tangible scenarios, such as our increasingly depleted livelihoods on Earth, both texts document our somewhat diminished expectations regarding the future. In a world where eating human protein is "reasonable" and its rejection merely "respectable", the preservation of humankind in space sets in motion a return to Hobbes's "natural state of man".

\author{
Johannes D. Kaminski, PhD \\ Institute of World Literature \\ Slovak Academy of Sciences \\ Dúbravská cesta 9 \\ 84104 Bratislava \\ Slovak Republic \\ jdkam@posteo.de \\ ORCID: https://orcid.org/0000-0002-9357-1149
}

